\title{
Caloramator boliviensis sp. nov., a thermophilic, ethanol-producing bacterium isolated from a hot spring
}

\author{
Carla Crespo, ${ }^{1,2}$ Tania Pozzo, ${ }^{1}$ Eva Nordberg Karlsson, ${ }^{1}$ \\ Maria Teresa Alvarez ${ }^{2}$ and Bo Mattiasson ${ }^{1}$ \\ ${ }^{1}$ Department of Biotechnology, Lund University, PO Box 124, S-22100 Lund, Sweden \\ ${ }^{2}$ Instituto de Investigaciones Fármaco Bioquímicas, Facultad de Ciencias Farmacéuticas y \\ Bioquímicas, Universidad Mayor de San Andrés, PO Box 3239, La Paz, Bolivia
}

Correspondence

Bo Mattiasson

Bo.Mattiasson@biotek.lu.se

\begin{abstract}
A novel moderately thermophilic, anaerobic, ethanol-producing bacterial strain, $45 \mathrm{~B}^{\top}$, was isolated from a mixed sediment water sample collected from a hot spring at Potosi, Bolivia. The cells were straight to slightly curved rods approximately $2.5 \mu \mathrm{m}$ long and $0.5 \mu \mathrm{m}$ wide. The strain was Gramstain-variable, spore-forming and monotrichously flagellated. Growth of the strain was observed at $45-65{ }^{\circ} \mathrm{C}$ and pH $5.5-8.0$, with optima of $60{ }^{\circ} \mathrm{C}$ and pH 6.5. The substrates utilized by strain $45 \mathrm{~B}^{\mathrm{T}}$ were xylose, cellobiose, glucose, arabinose, sucrose, lactose, maltose, fructose, galactose, mannose, glycerol, xylan, carboxymethylcellulose and yeast extract. The main fermentation product from xylose and cellobiose was ethanol ( 0.70 and $0.45 \mathrm{~g}$ ethanol per gram of consumed sugar, respectively). Acetate, lactate, propionate, carbon dioxide and hydrogen were also produced in minor quantities. 1,3-Propanediol was produced when glycerol-containing medium was supplemented with yeast extract. The major cellular fatty acids were anteiso- $\mathrm{C}_{15: 0}, \mathrm{C}_{16: 0}$, iso- $\mathrm{C}_{16: 0}, \mathrm{C}_{15: 1}$, iso- $\mathrm{C}_{14: 0}, \mathrm{C}_{13: 0}$ and $\mathrm{C}_{14: 0}$. The polar lipids diphosphatidylglycerol, phosphatidylglycerol, phosphatidylethanolamine, an aminoglycolipid and 15 other unidentified lipids were predominant. The DNA G+C content of strain $45 \mathrm{~B}^{\top}$ was 32.6 mol\%. Phylogenetic analysis based on $16 \mathrm{~S}$ rRNA gene sequence similarity revealed that strain $45 \mathrm{~B}^{\top}$ is located within the Gram-type positive Bacillus-Clostridium branch of the phylogenetic tree. On the basis of morphological and physiological properties and phylogenetic analysis, strain $45 \mathrm{~B}^{\top}$ represents a novel species, for which the name Caloramator boliviensis sp. nov. is proposed; the type strain is $45 \mathrm{~B}^{\top}\left(=\mathrm{DSM} 22065^{\top}=\right.$ CCUG $\left.^{\mathrm{T}} 57396^{\top}\right)$.
\end{abstract}

Growing concerns on environmental issues and finite fossil fuel supplies have stimulated an increasing interest in microbial fuel ethanol production using renewable raw materials (Olsson \& Hahn-Hagerdal, 1996; Wheals et al., 1999; Wyman, 1999; Cook \& Beyea, 2000; Zaldivar et al., 2001; Galbe \& Zacchi, 2002; Dien et al., 2003; Doi, 2003; Demain et al., 2005).

During the last two decades, saccharolytic, thermophilic, anaerobic bacteria have been intensively studied because of their potential for producing ethanol by metabolizing a very broad range of carbohydrates, including pentose sugars and their polymers. In addition, the thermophilic fermentation process has important advantages such as

Abbreviations: DPG, diphosphatidylglycerol; PE, phosphatidylethanolamine; PG, phosphatidylglycerol.

The GenBank/EMBL/DDBJ accession number for the 16S rRNA gene sequence of strain $45 \mathrm{~B}^{\top}$ is $\mathrm{FM} 244718$.

A supplementary figure and a supplementary table are available with the online version of this paper. easier product recovery, minimized contamination risk, reduced costs of pumping and stirring, and no aeration and cooling problems (Cook \& Morgan, 1994; Wiegel et al., 1985).

Some thermophilic anaerobic clostridia from clusters III, V and VII (according to the phylogenetic interrelationship established by Collins et al., 1994) have been reported to produce ethanol at high temperatures. Moreover, some other clostridial species that are phylogenetically distinct but conserve some physiological similarities have been reclassified in separate genera, including the genus Caloramator. Members of the Caloramator/Thermobrachium genera also produce ethanol, short chain fatty acids, carbon dioxide and hydrogen as end products of glucose fermentation (Collins et al., 1994; Patel et al., 1987; Plugge et al., 2000; Seyfried et al., 2002; Chrisostomos et al., 1996; Tarlera et al., 1997; Ogg \& Patel, 2009; Engle et al., 1996).

In this article, we report the isolation and characterization of a novel anaerobic, moderately thermophilic, fermentative, 
spore-forming and ethanol-producing bacterium (strain $45 \mathrm{~B}^{\mathrm{T}}$ ) belonging to the genus Caloramator.

Strain $45 \mathrm{~B}^{\mathrm{T}}$ was isolated from a mixed sediment water sample containing decayed leaves of eucalyptus (Eucalyptus sp.). The sample was collected from the hot spring Chaqui $\left(19^{\circ} 37.469^{\prime} \mathrm{S} 65^{\circ} 34.302^{\prime} \mathrm{W}\right)$ located in Potosi, Bolivia, at $3721 \mathrm{~m}$ above sea-level. The temperature and $\mathrm{pH}$ at the sampling point were $65{ }^{\circ} \mathrm{C}$ and 6.5 , respectively. The sample was collected in a sterile plastic flask by completely filling it. Subsequently, it was stored at room temperature prior to study.

For enrichment, isolation and cultivation, anaerobic mineral medium (AMM) was used as described by Angelidaki et al. (1990) with the following modifications: cysteine was omitted, the concentration of sodium sulphide was increased to $0.5 \mathrm{~g} \mathrm{l}^{-1}$ and the vitamin solution was replaced by vitamin solution DSM-141 (German Collection of Microorganisms and Cell Cultures; $10 \mathrm{ml}^{-1}$ ). Analytical grade chemicals and deionized water were used.

The medium was prepared by flushing with oxygen-free nitrogen according to the modified Hungate technique (Wiegel et al., 1985). Filter-sterilized solutions of vitamins, D-xylose and sodium sulphide were added after autoclaving $\left(121{ }^{\circ} \mathrm{C}, 20 \mathrm{~min}\right)$ and cooling the medium.

For initial sample enrichment, AMM supplemented with wheat straw $\left(12 \mathrm{~g} \mathrm{l}^{-1}\right)$ was used. The presence of ethanologenic micro-organisms was determined by quantifying ethanol production using the method described in this study.

For strain isolation, a biphasic AMM was used. The solid phase contained agar base ( $3 \%$ agar). D-Xylose $\left(5 \mathrm{~g} \mathrm{l}^{-1}\right)$ was supplemented to both phases as a carbon and energy source. Cultures were incubated at $60{ }^{\circ} \mathrm{C}(\mathrm{pH}$ 6.5) in darkness without shaking, unless otherwise stated. Single colonies were picked from the solid phase, transferred to fresh liquid AMM and incubated at $60{ }^{\circ} \mathrm{C}$ for 2 days. The biphasic culture procedure was repeated several times until a pure culture of strain $45 \mathrm{~B}^{\mathrm{T}}$ was obtained. The axenic culture was examined under a light microscope.

Routine examinations were performed using light microscopy (equipped with phase-contrast optics; Olympus). Gram staining was performed using the method of Hucker (Doetsch, 1981). The presence of spores in a liquid culture of strain $45 \mathrm{~B}^{\mathrm{T}}$ was examined by microscopy using Malachite green stain. Cells used for staining were harvested from exponential and/or early stationary growth phase.

The ability of the micro-organism to utilize different substrates was tested by using AMM supplemented with $5 \mathrm{~g}$ filter-sterilized substrates $\mathrm{l}^{-1}$. The cultures were incubated for 2 weeks and monitored for growth by measuring the optical density and $\mathrm{pH}$.

The effect of temperature and $\mathrm{pH}$ on growth was studied by incubating the strain $45 \mathrm{~B}^{\mathrm{T}}$ in $\mathrm{AMM}$ supplemented with cellobiose at temperatures ranging from 45 to $75{ }^{\circ} \mathrm{C}$ and from $\mathrm{pH} 5$ to 9. The $\mathrm{pH}$ was adjusted by using $1 \mathrm{M} \mathrm{H}_{2} \mathrm{SO}_{4}$. All $\mathrm{pH}$ measurements were done at room temperature. Bacterial growth was monitored by measuring the increase in optical density at $620 \mathrm{~nm}$ (Ultrospec 3000; Pharmacia Biotech). Acidification was studied with an API 20A test system (bioMérieux) after 2 days of incubation at the optimum growth temperature. All tests were repeated in triplicate.

Transmission electron microscopy was performed with a JEOL 100CX electron microscope. Samples were prepared by using the negative stain with uranyl acetate as described by Spurr (1969). Scanning electron microscopy was performed with a JSM-5600 LV microscope. Cells were harvested from a fresh liquid culture. The sample was prepared as described by Reynolds (1963).

Substrates and fermentation products were analysed in acidified and filtered samples by HPLC (JASCO) equipped with an HPX-87H ion-exchange column (Bio-Rad) at $55{ }^{\circ} \mathrm{C}$ and a refractive index detector. Sulphuric acid $(5 \mathrm{mM})$ was used as a mobile phase $\left(0.6 \mathrm{ml} \mathrm{min}^{-1}\right)$. Determination of carbon dioxide was performed by GC as described by Parawira et al. (2004). Hydrogen was analysed offline by GC (6890 Network GC system, Agilent Technologies). The GC was fitted with an 80/100 Haye Sep-N, $9 \mathrm{ft}, 1 / 8$ stainless steel column, a molecular sieve $(60 / 80$ Molesieve $5 \mathrm{~A}, 6 \mathrm{ft}, 1 / 8)$ and a thermal conductivity detector. Argon was used as the carrier gas at a flow rate of $46.6 \mathrm{ml} \mathrm{min}{ }^{-1}$. The column temperature was $60{ }^{\circ} \mathrm{C}$ and the injector and detector temperatures were 105 and $150{ }^{\circ} \mathrm{C}$, respectively.

Chemical characterization of strain $45 \mathrm{~B}^{\mathrm{T}}$, including the analysis of respiratory quinones, polar lipids and fatty acids, was carried out. Cells subjected to chemotaxonomic analysis were grown under the conditions as described for temperature and $\mathrm{pH}$ studies. Respiratory quinones and polar lipids were analysed by the Identification Service of the DSMZ and Dr B. J. Tindall, DSMZ, Braunschweig, Germany. Respiratory lipoquinones and polar lipids were extracted from $100 \mathrm{mg}$ freeze-dried cell material using the two-stage method described by Tindall (1990a, b). Respiratory quinones were extracted using methanol/ hexane (Tindall, 1990a, b), followed by phase separation into hexane. Polar lipids were extracted by adjusting the remaining methanol/ $0.3 \%$ aqueous $\mathrm{NaCl}$ phase (containing the cell debris) to give a chloroform $/$ methanol $/ 0.3 \%$ aqueous $\mathrm{NaCl}$ mixture $1: 2: 0.8$ (by vol.). The extraction solvent was stirred overnight and the cell debris was pelleted by centrifugation. Polar lipids were recovered into the chloroform phase by adjusting the chloroform/ methanol $/ 0.3 \%$ aqueous $\mathrm{NaCl}$ mixture to a ratio of $1: 1: 0.9$ (by vol.).

Respiratory lipoquinones were separated into their different classes (menaquinones, ubiquinones, etc.) by TLC on silica gel (Macherey-Nagel), using hexane/tert-butylmethylether (9:1, $\mathrm{v} / \mathrm{v})$ as solvent. UV absorbing bands corresponding to the different quinone classes (e.g. menaquinones or ubiquinones) 
were removed from the plate and further analysed by HPLC. This step was carried out on an LDC Analytical HPLC (Thermo Separation Products) fitted with a reverse phase column (Macherey-Nagel, $2 \mathrm{~mm} \times 125 \mathrm{~mm}, 3 \mu \mathrm{m}$, RP18) using methanol/heptane $(9: 1, \mathrm{v} / \mathrm{v})$ as the eluent. Respiratory lipoquinones were detected at $269 \mathrm{~nm}$.

Polar lipids were separated by two-dimensional silica gel TLC (Macherey-Nagel). The first direction was developed in chloroform/methanol/water $(65: 25: 4$, by vol.), and the second was in chloroform/methanol/acetic acid/water $(80: 12: 15: 4$, by vol.). Total lipid material and specific functional groups were detected using dodecamolybdophosphoric acid (total lipids), Zinzadze reagent (phosphate), ninhydrin (free amino groups), periodate-Schiff $(\alpha$-glycols), Dragendorff reagent (quaternary nitrogen) and $\alpha$-naphthol-sulphuric acid (glycolipids) according to the procedure described by Tindall et al. (2007).

For determining the fatty acid profile, fatty acid methyl esters were prepared directly from cells of strain $45 \mathrm{~B}^{\mathrm{T}}$, as described by Miller \& Berger (1985) with minor modifications. $\mathrm{NaOH}(100 \mathrm{ml}, 1.2 \mathrm{M})$ in $50 \%$ methanol was added to $4 \mathrm{~g}$ freeze-dried cells; the mix was then vortexed and placed in boiling water for $30 \mathrm{~min}$. Subsequently, and after cooling down to room temperature, $200 \mathrm{ml} 6 \mathrm{M} \mathrm{HCl}$ in methanol $(325: 275, \mathrm{v} / \mathrm{v})$ was added. The mixture was placed at $80{ }^{\circ} \mathrm{C}$ for $10 \mathrm{~min}$. After cooling, $125 \mathrm{ml}$ hexane/ tert-butylmethylether $(1: 1, \mathrm{v} / \mathrm{v})$ was added. The mixture was then agitated in a shaker (60 r.p.m.) for $10 \mathrm{~min}$. The lower aqueous phase was discarded and $300 \mathrm{ml} 0.3 \mathrm{M}$ $\mathrm{NaOH}$ was added. The mixture was agitated for an additional $5 \mathrm{~min}$. The lower aqueous phase was discarded and the same procedure was repeated. Subsequently, the upper phase was centrifuged at $15300 \mathrm{~g}$ for $20 \mathrm{~min}$ to remove remaining colloidal particles. The supernatant was then concentrated to $2 \mathrm{ml}$ under a nitrogen gas stream. Prior to the analysis, the sample was diluted 100 -fold and filtered through a $0.2 \mu \mathrm{m}$ polystyrene membrane. Fatty acid methyl ester analysis was carried out using a Varian 3400 GC system equipped with a flame-ionization detector and an automatic sampler. Factor four capillary column $(15 \mathrm{~m} \times 0.25 \mathrm{~mm}$; Varian) was used to separate fatty acid methyl esters. The carrier gas was helium at $1.38 \times 10^{-1} \mathrm{MPa}$. The temperature programme for separation was: initial temperature of $50{ }^{\circ} \mathrm{C}$ held for $2 \mathrm{~min}$, then increased to $250{ }^{\circ} \mathrm{C}$ at $20{ }^{\circ} \mathrm{C} \mathrm{min}^{-1}$ and held for $3 \mathrm{~min}$. Injector temperature was maintained at $270{ }^{\circ} \mathrm{C}$ and detector temperature was kept constant at $275{ }^{\circ} \mathrm{C}$

Genomic DNA was extracted as described by Marmur (1961). Purity and quantification of the DNA was measured by NanoDrop ND-1000 UV-Vis Spectrophotometer (NanoDrop Technologies). Amplification of the 16S rRNA gene was performed using Phusion polymerase (Finnzymes) and bacterial universal primers 8-27F and 1422R (Weisburg et al., 1991). PCR products were purified using a QIAquick PCR Purification kit (Qiagen). The 16S rRNA gene was sequenced at GATC Biotech AG (Konstanz, Germany) and analysed using Vector NTI 10 software (Invitrogen). The 16S rRNA gene sequence of strain $45 \mathrm{~B}^{\mathrm{T}}$ was submitted to GenBank/EMBL and similar sequences were found using the BLAST algorithm. To construct the phylogenetic tree, only sequences from members of species of the genera Caloramator/Thermobrachium with validly published names were taken into consideration. Clostridium butyricum DSM $2478^{\mathrm{T}}$ (X68177.1), the type strain of Clostridium sensu stricto, was used as an outgroup.

Assays of genomic DNA G $+\mathrm{C}$ content (mol\%) and DNADNA hybridization were carried out by the Deutsche Sammlung von Mikroorganismen und Zellkulturen (DSMZ, Braunschweig, Germany). DNA-DNA hybridization was performed between strain $45 \mathrm{~B}^{\mathrm{T}}$ and Caloramator viterbiensis DSM $13723^{\mathrm{T}}$. Strain $45 \mathrm{~B}^{\mathrm{T}}$ was cultured as described previously and the reference strain was cultured as recommended in the culture collection catalogue of the DSMZ.

For sample enrichment and primary isolation, AMM containing wheat straw was inoculated with $1 \%(\mathrm{v} / \mathrm{v})$ of the sample and incubated at $60{ }^{\circ} \mathrm{C}$ until ethanol was detected as a product. In addition, dilution series of this enrichment culture were inoculated in AMM supplemented with D-xylose $\left(5 \mathrm{~g} \mathrm{l}^{-1}\right)$. After subsequent transfers, $1 \%(\mathrm{v} / \mathrm{v})$ of the final culture was inoculated in the liquid phase of a biphasic medium containing D-xylose and incubated until turbidity was observed. Subsequently, the serum bottle was turned so that the surface of the solid phase was covered by the liquid for approximately $1 \mathrm{~h}$. Then, the serum bottle was turned to its original position and incubated for $48 \mathrm{~h}$. White, uniformly round, convex and mucous colonies of strain $45 \mathrm{~B}^{\mathrm{T}}$ (1.0-1.5 $\mathrm{mm}$ in diameter) were formed.

Single colonies were picked and suspended in about $30 \mathrm{ml}$ AMM containing D-xylose $\left(5 \mathrm{~g} \mathrm{l}^{-1}\right)$. Cells $(1 \% \mathrm{v} / \mathrm{v})$ were subcultured in liquid medium of the same composition to confirm the production of ethanol.

Strain $45 \mathrm{~B}^{\mathrm{T}}$ was Gram-variable; it stained Gram-negative during exponential phase and Gram-positive when the stationary phase was reached. Cells of strain $45 \mathrm{~B}^{\mathrm{T}}$ were terminal spore-forming rods of approximately $2.5 \mu \mathrm{m}$ long and $0.5 \mu \mathrm{m}$ wide (Fig. 1a). Cells occurred singly or in chains and were monotrichously flagellated (Fig. 1b).

The substrates utilized by strain $45 \mathrm{~B}^{\mathrm{T}}$ included xylose, cellobiose, glucose, arabinose, sucrose, lactose, maltose, fructose, galactose, mannose, glycerol, xylan, carboxymethylcellulose and yeast extract.

The primary end products formed during D-xylose and cellobiose fermentation included ethanol, acetate, lactate, propionate, carbon dioxide and hydrogen. Fermentation of D-xylose and cellobiose yielded ethanol as the main product $(0.70$ and $0.45 \mathrm{~g}$ ethanol per gram of sugar consumed, respectively). The pattern obtained suggests a conversion according to the following equations.

The fermentation balance when $0.73 \mathrm{mM}$ D-xylose (equation 1) and $11.7 \mathrm{mM}$ cellobiose (equation 2) were 


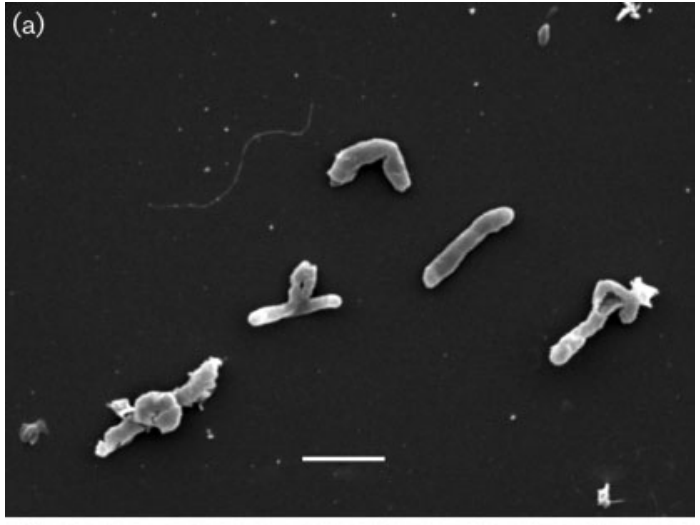

(b)

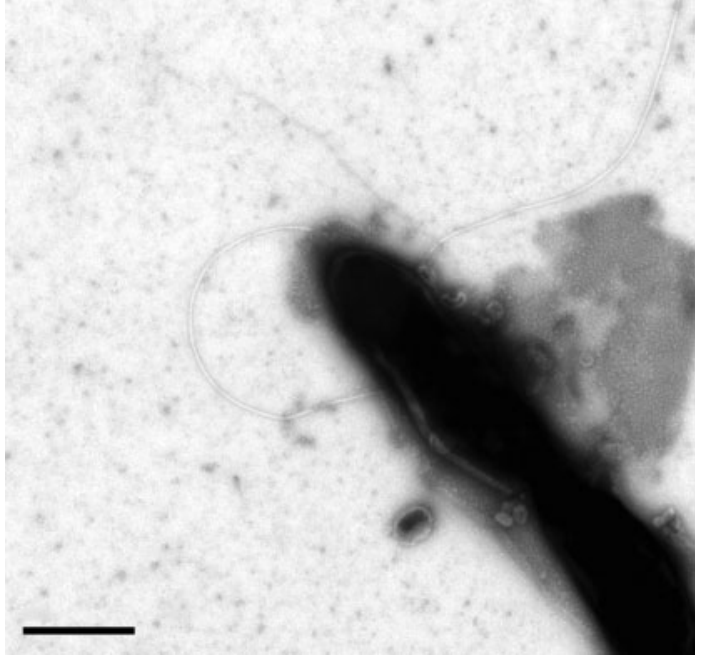

Fig. 1. Electron micrographs of strain $45 B^{\top}$. (a) Scanning electron micrograph of cells of strain $45 \mathrm{~B}^{\top}$ showing swollen ends (reminiscent of prespores) and bulging sections in the middle of elongated cells; bar, $2 \mu \mathrm{m}$. (b) Transmission electron micrograph of strain $45 \mathrm{~B}^{\top}$, negatively stained, showing monotrichous flagellum; bar, $0.5 \mu \mathrm{m}$.

consumed by strain $45 \mathrm{~B}^{\mathrm{T}}$ grown to the stationary phase is described as follows (in mol quantities):

$\mathrm{C}_{5} \mathrm{H}_{10} \mathrm{O}_{5}+\mathrm{H}_{2} \mathrm{O} \rightarrow 2.30 \mathrm{C}_{2} \mathrm{H}_{5} \mathrm{OH}+0.14 \mathrm{CH}_{3} \mathrm{COOH}+$ $0.01 \mathrm{CH}_{3} \mathrm{CHOHCOOH}+0.03 \mathrm{CO}_{2}+0.09 \mathrm{H}_{2}+$ biomass (equation 1)

$\mathrm{C}_{12} \mathrm{H}_{22} \mathrm{O}_{11}+\mathrm{H}_{2} \mathrm{O} \rightarrow 3.34 \mathrm{C}_{2} \mathrm{H}_{5} \mathrm{OH}+0.90 \mathrm{CH}_{3} \mathrm{COOH}+$ $0.02 \mathrm{CH}_{3} \mathrm{CHOHCOOH}+0.09 \mathrm{CH}_{3} \mathrm{CH}_{2} \mathrm{COOH}+1.91 \mathrm{CO}_{2}$ $+0.92 \mathrm{H}_{2}+$ biomass

(equation 2)

Strain $45 \mathrm{~B}^{\mathrm{T}}$ grew strictly anaerobically at $45-65^{\circ} \mathrm{C}$, with optimum growth at $60{ }^{\circ} \mathrm{C}$. No growth was observed at temperatures above $65{ }^{\circ} \mathrm{C}$ after 3 weeks of incubation (Fig. 2a). The $\mathrm{pH}$ range for growth was 5.5-8.0, with an optimum pH between 6.5 and 7.0. No growth was detected at $\mathrm{pH} 5.0$ or 9.0 (Fig. 2b). The shortest doubling time under optimal growth conditions was $1.4 \mathrm{~h}$.
Acid was produced by strain $45 \mathrm{~B}^{\mathrm{T}}$ from D-glucose, Dmannitol, lactose (bovine origin), sucrose, maltose, salicin, D-xylose, L-arabinose, gelatin (bovine origin), aesculin ferric citrate, glycerol, cellobiose, D-mannose, melezitose, raffinose, D-sorbitol, L-rhamnose and trehalose, but it is not produced from L-tryptophan.

Chemotaxonomic analysis revealed the absence of respiratory quinones in strain $45 \mathrm{~B}^{\mathrm{T}}$. Strain $45 \mathrm{~B}^{\mathrm{T}}$ possessed a rather complex polar lipid profile as shown by TLC (Fig. S1, available in IJSEM Online). Nineteen resolved lipid spots included diphosphatidylglycerol (DPG), phosphatidylglycerol (PG), phosphatidylethanolamine (PE), an aminoglycolipid, 11 other unidentified phospholipids, three unidentified aminolipids and one unidentified lipid. Fatty acid analysis of strain $45 \mathrm{~B}^{\mathrm{T}}$ showed a complex profile in which saturated and branched acids predominated; anteiso- $\mathrm{C}_{15: 0}$ was found to be the major compound (35\%) and other branched acids such as iso- $\mathrm{C}_{14: 0}$ and iso- $\mathrm{C}_{16: 0}$ were found in minor amounts (7 and $10 \%$, respectively). The saturated acids detected were $\mathrm{C}_{13: 0}(6 \%), \mathrm{C}_{14: 0}(4 \%)$ and $\mathrm{C}_{16: 0}(16 \%)$. The only unsaturated acid found in strain $45 \mathrm{~B}^{\mathrm{T}}$ was $\mathrm{C}_{15: 1}(10 \%)$.

The almost complete 16S rRNA gene sequence of strain $45 \mathrm{~B}^{\mathrm{T}}$, comprising $1437 \mathrm{nt}$, was determined. Phylogenetic analysis showed that strain $45 \mathrm{~B}^{\mathrm{T}}$ clustered together with the type strain of Caloramator viterbiensis (Seyfried et al., 2002) as a distinct lineage within the radiation of the previously described genera Caloramator/Thermobrachium (Fig. 3).

The 16S rRNA gene sequence of strain $45 \mathrm{~B}^{\mathrm{T}}$ had $91.8-99.4 \%$ similarities to those of other members of the same genus (Table S1), and had $86.6 \%$ similarity with Clostridium butyricum DSM $2478^{\mathrm{T}}$ 16S rRNA gene sequence. Multiple alignment was performed by using the programs CLUSTAL $\mathrm{W}$ and MUSCLE and the default settings for the 16S rRNA gene alignment excluded smaller final blocks, gap positions within the final blocks and less strict flanking positions and included contiguous non-conserved positions, if any. The phylogenetic tree was constructed from evolutionary distances using the neighbour-joining method. Tree topology was examined by bootstrap analyses on the branches (Fig. 3 ) and it clearly supports the close relationship between strain $45 \mathrm{~B}^{\mathrm{T}}$ and the type strain of Caloramator viterbiensis and their distinct lineage within the Caloramator/Thermobrachium cluster. $16 \mathrm{~S}$ rRNA gene sequence analysis indicated that strain $45 \mathrm{~B}^{\mathrm{T}}$ was most closely related to Caloramator viterbiensis (99.4\% similarity to the type strain) (Table S1).

In spite of the high similarity of the 16S rRNA gene sequences of strain $45 \mathrm{~B}^{\mathrm{T}}$ and Caloramator viterbiensis DSM $13723^{\mathrm{T}}$ (>99\%), the DNA-DNA relatedness between them both was only $19.5 \%$. This value is lower than the recommended value $(70 \%)$ required to recognize them as members of the same species (Wayne et al., 1987). The genomic DNA G $+C$ content of strain $45 \mathrm{~B}^{\mathrm{T}}$ was $32.6 \mathrm{~mol} \%$.

The described strain, $45 \mathrm{~B}^{\mathrm{T}}$, was isolated based on its ability to ferment $\mathrm{D}$-xylose and cellobiose to ethanol as main 
(a)

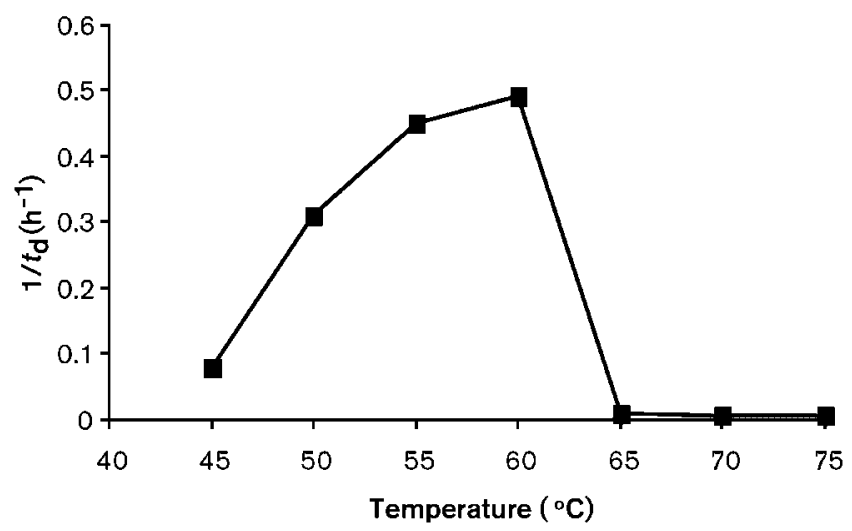

(b)

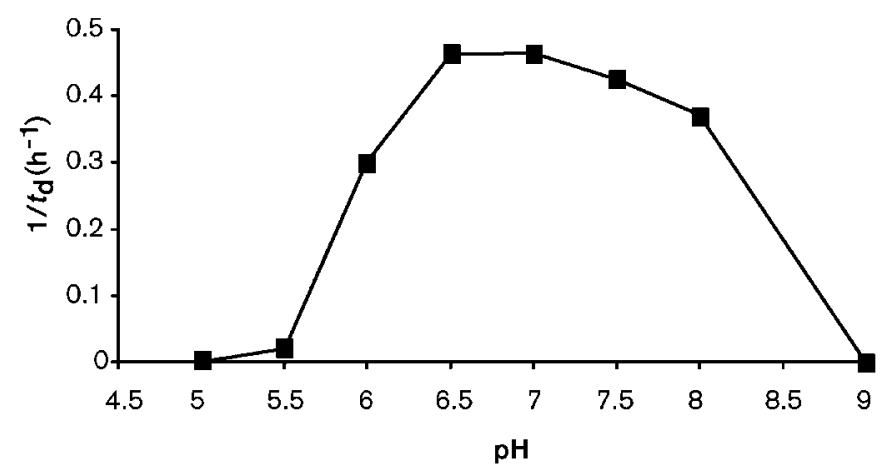

Fig. 2. Effect of temperature (at $\mathrm{pH} 6.5 ; \mathrm{a})$ and $\mathrm{pH}\left(\right.$ at $\left.60{ }^{\circ} \mathrm{C} ; \mathrm{b}\right)$ on growth of strain $45 \mathrm{~B}^{\top}$. $t_{\mathrm{d}}$, Doubling time.

fermentation product, which is the most remarkable difference between this strain and other members of the genera Caloramator/Thermobrachium. However, it has been reported that some members of this group produce minor quantities of ethanol from glucose (Collins et al., 1994; Patel et al., 1987; Plugge et al., 2000; Seyfried et al., 2002; Chrisostomos et al., 1996; Tarlera et al., 1997; Ogg \& Patel, 2009; Engle et al., 1996).

Most strains of the genera Caloramator/Thermobrachium produce acetate and minor quantities of ethanol, lactate, propionate, butyrate, formate, valerate, carbon dioxide and hydrogen as end products of the fermentative metabolism of carbohydrates. Moreover, strain $45 \mathrm{~B}^{\mathrm{T}}$ produces significant amounts of ethanol and acetate, lactate, propionate, carbon dioxide and hydrogen as minor products. Since $45 \mathrm{~B}^{\mathrm{T}}$ was primarily isolated using wheat straw and, based on the fact that it utilizes various substrates, it may have a wide range of saccharolytic activities, which could be used for direct microbial conversion of lignocellulosic material into ethanol.
In addition, the conversion of glycerol to 1,3-propanediol has been demonstrated for strain $45 \mathrm{~B}^{\mathrm{T}}$ in liquid medium (AMM); this activity was enhanced by supplementation with yeast extract. This ability has also been reported for its closest relative, Caloramator viterbiensis (Seyfried et al., 2002). The ability to utilize glycerol has not yet been studied for other strains from the genera Caloramatorl Thermobrachium.

The temperature range for growth of strain $45 \mathrm{~B}^{\mathrm{T}}$ is more similar to those of Caloramator coolhaasii and Caloramator viterbiensis than those of other Caloramator species. However, since strain $45 \mathrm{~B}^{\mathrm{T}}$ has an optimum growth temperature around $60{ }^{\circ} \mathrm{C}$, it is considered to be a moderately thermophilic bacterium.

The shortest doubling time for growth of strain $45 \mathrm{~B}^{\mathrm{T}}$ under optimum conditions with cellobiose as a substrate was found to be around $1.4 \mathrm{~h}$, which is half of the doubling time reported for Caloramator viterbiensis, its closest relative (Seyfried et al., 2002). Moreover, this value is

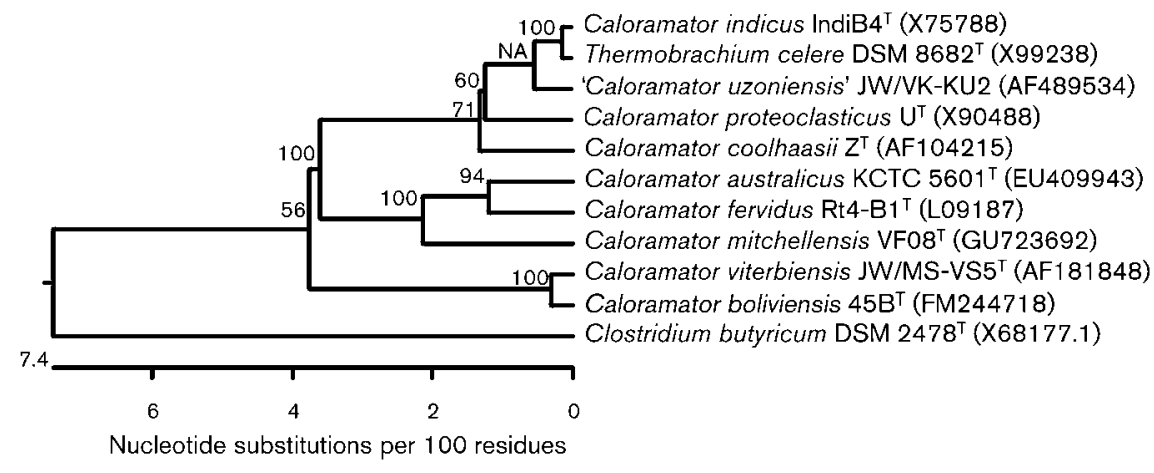

Fig. 3. Phylogenetic dendrogram based on $16 \mathrm{~S}$ rRNA gene sequence comparisons. The neighbour-joining tree was reconstructed from distance matrices. Bootstrap values (bootstrap trials, 1000; seed 111; values given as percentages) are shown at branch points. Bar, number of nucleotide substitutions per 100 residues. 
several times higher than the doubling times reported for other members of the Caloramator/Thermobrachium cluster and other taxa of the genus Clostridium cluster I.

The formation of spores and/or thermoresistant cells has been demonstrated for two species of Caloramator (Caloramator fervidus and Caloramator proteoclasticus) and for strain $45 \mathrm{~B}^{\mathrm{T}}$. In contrast, Caloramator viterbiensis, Caloramator australicus, Caloramator coolhaasii and Caloramator indicus lack this ability.

The presence of peritrichous flagella has only been reported for Thermobrachium celere, Caloramator proteoclasticus and Caloramator australicus. In contrast, strain $45 \mathrm{~B}^{\mathrm{T}}$ possessed a monotrichous flagellum. Other members of the genera Caloramator/Thermobrachium, including Caloramator viterbiensis, lack flagella.

Lipid composition data for strain $45 \mathrm{~B}^{\mathrm{T}}$ revealed the absence of respiratory lipoquinones. In a previous study carried out by Yamamoto et al. (1998), menaquinone MK-7 was found in Caloramator fervidus; however, no other reports of quinone composition in Caloramator/Thermobrachium species are available so far. Although the results obtained in this study revealed the absence of quinones, as in most clostridia and/or related genera, further systematic studies are necessary before considering quinone analyses as a taxonomic tool for this particular genus. Examination of the polar lipid profile of strain $45 \mathrm{~B}^{\mathrm{T}}$ revealed some unusual features, including the absence of glycolipids and the presence of several unidentified phospholipids. The presence of glycolipids is very significant for saccharolytic bacteria, e.g. Clostridium thermocellum, since glycolipids on the surface serve for recognition and/or binding to substrates (e.g. cellulose, xylan) (Herrero et al., 1982). An interesting physiological feature of strain $45 \mathrm{~B}^{\mathrm{T}}$ is the ability to utilize a wide spectrum of substrates in spite of the absence of glycolipids. In common with other Gram-positive bacteria, strain $45 \mathrm{~B}^{\mathrm{T}}$ contains PE, DPG and PG. Aminophospholipids such as $\mathrm{PE}$ and their respective plasmalogens are major phospholipids of the saccharolytic, butyric-acid-producing clostridia, including Clostridium butyricum, Clostridium beijerinckii, Clostridium acetobutylicum and related species (Johnston \& Goldfine, 1983).

Chemotaxonomic analyses revealed the predominance of iso-branched fatty acids, in particular iso- $\mathrm{C}_{15: 0}$, in thermophilic clostridia, which have been reclassified into new genera (Yamamoto et al., 1998). Moreover, it was found that iso- $\mathrm{C}_{15: 0}$ is the major fatty acid present in Caloramator fervidus. In contrast, the major cellular fatty acid found in strain $45 \mathrm{~B}^{\mathrm{T}}$ was anteiso- $\mathrm{C}_{15: 0}$.

Phylogenetic analysis (Fig. 3) showed that strain $45 \mathrm{~B}^{\mathrm{T}}$ is most closely related to the type strains of Caloramator viterbiensis and other members of the Caloramator cluster including Thermobrachium celere. The Caloramator cluster forms part of the Gram-type-positive Bacillus-Clostridium branch and is most closely related to cluster I of the Clostridium branch. All species of the Caloramator cluster are thermophilic, chemo-organoheterotrophic, anaerobic bacteria exhibiting low DNA G $+\mathrm{C}$ content, which are also characteristics of strain $45 \mathrm{~B}^{\mathrm{T}}$. Table 1 shows a comparison of the morphological and physiological features of all Caloramator/Thermobrachium species.

The DNA $\mathrm{G}+\mathrm{C}$ content determined for strain $45 \mathrm{~B}^{\mathrm{T}}$ (32.6 mol\%) is close to that of Thermobrachium celere, Caloramator viterbiensis, Caloramator proteoclasticus and Caloramator coolhaasii (31-32 mol\%), whereas the values reported for Caloramator indicus, Caloramator australicus and Caloramator fervidus differ significantly $(25,34$ and $39 \mathrm{~mol} \%$, respectively); this may be due to the different methods used for determination.

Although strain $45 \mathrm{~B}^{\mathrm{T}}$ is related to other Caloramatorl Thermobrachium species and has similar physiological properties, it shows certain characteristics that differ significantly from those of the type strains of species of the genera Caloramator/Thermobrachium (Table 1).

The differences in morphological and physiological properties and the low level of $16 \mathrm{~S}$ rRNA gene sequence similarity of strain $45 \mathrm{~B}^{\mathrm{T}}$ suggest that this strain can be classified as a representative of a novel species of the genus Caloramator.

\section{Description of Caloramator boliviensis sp. nov.}

Caloramator boliviensis (bo.li.vi.en'sis. N.L. masc. adj. boliviensis of or belonging to Bolivia, the country from which the organism was first isolated).

Cells are straight to slightly curved spore-forming rods, approximately $2.5 \mu \mathrm{m}$ long and $0.5 \mu \mathrm{m}$ wide. Cells are Gram-stain-variable and occur singly or in chains. Cells are strictly anaerobic and motile by means of a monotrichous flagellum. White, uniformly round, convex and mucous colonies (1.0-1.5 mm in diameter) form after $48 \mathrm{~h}$ on biphasic AMM. Growth is observed on xylose, cellobiose, glucose, arabinose, sucrose, lactose, maltose, fructose, galactose, mannose, glycerol, xylan, carboxymethylcellulose and yeast extract. Fermentation of xylose and cellobiose yields ethanol as the main end product $(0.70$ or $0.45 \mathrm{~g}$ ethanol per gram of xylose or cellobiose consumed, respectively). Acetate, lactate, propionate, carbon dioxide and hydrogen are also produced in minor quantities. Glycerol is converted to 1,3-propanediol when AMM is supplemented with yeast extract. Acid is produced from Dglucose, D-mannitol, lactose (bovine origin), sucrose, maltose, salicin, D-xylose, L-arabinose, gelatin (bovine origin), aesculin ferric citrate, glycerol, cellobiose, Dmannose, melezitose, raffinose, D-sorbitol, L-rhamnose and trehalose. The shortest doubling time $(1.4 \mathrm{~h})$ occurs at $60{ }^{\circ} \mathrm{C}$ and $\mathrm{pH} 6.5$, using cellobiose as a sole carbon and energy source. Polar lipids such as DPG, PG, PE, an aminoglycolipid plus 15 other unidentified lipids, and fatty acids including anteiso- $\mathrm{C}_{15: 0}, \mathrm{C}_{16: 0}$, iso- $\mathrm{C}_{16: 0}, \mathrm{C}_{15: 1}$, iso- $\mathrm{C}_{14: 0}, \mathrm{C}_{13: 0}$ and $\mathrm{C}_{14: 0}$ are predominant. 
Table 1. Characteristics differentiating strain $45 \mathrm{~B}^{\top}$ from its phylogenetic relatives

Taxa: 1, strain $45 \mathrm{~B}^{\mathrm{T}} ; 2$, Caloramator viterbiensis JW/MS-VS5 ${ }^{\mathrm{T}}$ (Seyfried et al., 2002); 3, Caloramator fervidus RT4-B1 ${ }^{\mathrm{T}}$ (Patel et al., 1987); 4, Caloramator indicus IndiB4 ${ }^{\mathrm{T}}$ (Chrisostomos et al., 1996); 5, Caloramator proteoclasticus $\mathrm{U}^{\mathrm{T}}$ (Tarlera et al., 1997); 6, Caloramator coolhaasii $\mathrm{Z}^{\mathrm{T}}$ (Plugge et al., 2000); 7, Caloramator australicus KCTC 5601 ${ }^{\mathrm{T}}$ (Ogg \& Patel, 2009); 8, Thermobrachium celere JW/YL-NZ35 ${ }^{\mathrm{T}}$ (Engle et al., 1996). NR, Not reported.

\begin{tabular}{|c|c|c|c|c|c|c|c|c|}
\hline Characteristic & 1 & 2 & 3 & 4 & 5 & 6 & 7 & 8 \\
\hline Shortest doubling time $(\mathrm{h})$ & 1.40 & 2.80 & 0.75 & 0.33 & 0.50 & 1.00 & NR & 0.17 \\
\hline \multicolumn{9}{|l|}{ Growth temperature $\left({ }^{\circ} \mathrm{C}\right)$} \\
\hline Optimum & 60 & 58 & 68 & $60-65$ & 55 & $50-55$ & 60 & 66 \\
\hline \multicolumn{9}{|l|}{ Growth $\mathrm{pH}$} \\
\hline Range & $5.5-8.0$ & $5.0-7.8$ & $5.5-9.0$ & $6.2-9.2$ & $6.0-9.5$ & $6.0-8.5$ & $5.0-9.0$ & $5.4-9.5$ \\
\hline DNA G $+C$ content $(\mathrm{mol} \%)$ & 33 & 32 & 39 & 26 & 31 & 32 & 34 & 31 \\
\hline Spores or heat-resistant cells & + & - & + & - & + & - & + & - \\
\hline Flagella* & $\mathrm{M}$ & - & - & - & $\mathrm{P}$ & - & $\mathrm{P}$ & $\mathrm{P}$ \\
\hline \multicolumn{9}{|l|}{ Utilization of: } \\
\hline Xylose & + & - & + & $\mathrm{NR}$ & - & + & + & - \\
\hline Cellobiose & + & + & NR & + & + & + & + & - \\
\hline
\end{tabular}

${ }^{*} \mathrm{M}$, Monotrichous; $\mathrm{P}$, peritrichous.

The type strain, $45 \mathrm{~B}^{\mathrm{T}}\left(=\mathrm{DSM} 22065^{\mathrm{T}}=\mathrm{CCUG} 57396^{\mathrm{T}}\right)$, was isolated from Chaqui hot spring located in Potosi, Bolivia. The DNA G+C content of the type strain is $32.6 \mathrm{~mol} \%$.

\section{Acknowledgements}

This research has been supported by the Swedish International Development Cooperation Agency (Sida) and the Swedish Agency for Research Cooperation with Developing Countries (SAREC). Thanks to Maria Karlsson for collecting samples from Bolivian extreme environments.

\section{References}

Angelidaki, I., Petersen, S. P. \& Ahring, B. K. (1990). Effects of lipids on thermophilic anaerobic digestion and reduction of lipid inhibition upon addition of bentonite. Appl Microbiol Biotechnol 33, 469-472.

Chrisostomos, S., Patel, B. K. C., Dwivedi, P. P. \& Denman, S. E. (1996). Caloramator indicus sp. nov., a new thermophilic anaerobic bacterium isolated from the deep-seated non volcanically heated waters of an Indian artesian aquifer. Int J Syst Bacteriol 46, 497-501.

Collins, M. D., Lawson, P. A., Willems, A., Cordoba, J. J., FernandezGarayzabal, J., Garcia, P., Cai, J., Hippe, H. \& Farrow, J. A. (1994). The phylogeny of the genus Clostridium: proposal of five new genera and eleven new species combinations. Int J Syst Bacteriol 44, 812-826.

Cook, J. \& Beyea, J. (2000). Bioenergy in the United States: progress and possibilities. Biomass Bioenergy 18, 441-455.

Cook, G. M. \& Morgan, H. W. (1994). Hyperbolic growth of Thermoanaerobacter thermohydrosulfuricus (Clostridium thermohydrosulfuricum) increases ethanol production in $\mathrm{pH}$-controlled batch culture. Appl Microbiol Biotechnol 41, 84-89.
Demain, A. L., Newcomb, M. \& Wu, J. H. (2005). Cellulase, clostridia, and ethanol. Microbiol Mol Biol Rev 69, 124-154.

Dien, B. S., Cotta, M. A. \& Jeffries, T. W. (2003). Bacteria engineered for fuel ethanol production: current status. Appl Microbiol Biotechnol 63, 258-266.

Doetsch, R. N. (1981). Determinative methods of light microscopy. In Manual of Methods for General Microbiology, pp. 21-33. Edited by P. Gerhardt, R. G. E. Murray, R. N. Costilow, E. W. Nester, A. Wood, N. R. Krieg \& G. B. Phillips. Washington, DC: American Society for Microbiology.

Doi, R. H. (2003). Microbial conversion of corn stalks to riches. J Bacteriol 185, 701-702.

Engle, M., Li, Y., Rainey, F., DeBlois, S., Mai, V., Reichert, A., Mayer, F., Messner, P. \& Wiegel, J. (1996). Thermobrachium celere gen. nov., sp. nov., a rapidly growing thermophilic, alkalitolerant, and proteolytic obligate anaerobe. Int J Syst Bacteriol 46, 10251033.

Galbe, M. \& Zacchi, G. (2002). A review of the production of ethanol from softwood. Appl Microbiol Biotechnol 59, 618-628.

Herrero, A. A., Gomez, R. F. \& Roberts, M. F. (1982). Ethanol-induced changes in the membrane lipid composition of Clostridium thermocellum. Biochim Biophys Acta 693, 195-204.

Johnston, N. C. \& Goldfine, H. (1983). Lipid composition in the classification of the butyric acid-producing clostridia. J Gen Microbiol 129, 1075-1081.

Marmur, J. (1961). A procedure for the isolation of deoxyribonucleic acid from micro-organisms. J Mol Biol 3, 208-218.

Miller, L. \& Berger, T. (1985). Bacteria Identification by Chromatography of Whole Cell Fatty Acids. Hewlett-Packard Application Note 228-28. Palo Alto, CA: Hewlett-Packard Co.

Ogg, C. D. \& Patel, B. K. (2009). Caloramator australicus sp. nov., a thermophilic, anaerobic bacterium from the Great Artesian Basin of Australia. Int J Syst Evol Microbiol 59, 95-101. 
Olsson, L. \& Hahn-Hagerdal, B. (1996). Fermentation of lignocellulosic hydrolysates for ethanol production. Enzyme Microb Technol 18, 312-331.

Parawira, W., Murto, M., Read, J. S. \& Mattiasson, B. (2004). Volatile fatty acids production during anaerobic mesophilic digestion of solid potato waste. J Chem Technol Biotechnol 79, 673-677.

Patel, B. K. C., Monk, C., Littleworth, H., Morgan, H. W. \& Daniel, R. M. (1987). Clostridium fervidus sp. nov., a new chemoorganotrophic acetogenic thermophile. Int J Syst Bacteriol 37, 123-126.

Plugge, C. M., Zoetendal, E. G. \& Stams, A. J. M. (2000). Caloramator coolhaasii sp. nov., a glutamate-degrading, moderately thermophilic anaerobe. Int J Syst Evol Microbiol 50, 1155-1162.

Reynolds, E. S. (1963). The use of lead citrate at high $\mathrm{pH}$ as an electron-opaque stain in electron microscopy. J Cell Biol 17, 208-212.

Seyfried, M., Lyon, D., Rainey, F. A. \& Wiegel, J. (2002). Caloramator viterbensis sp. nov., a novel thermophilic, glycerol-fermenting bacterium isolated from a hot spring in Italy. Int J Syst Evol Microbiol 52, 1177-1184.

Spurr, A. R. (1969). A low-viscosity epoxy resin embedding medium for electron microscopy. J Ultrastruct Res 26, 31-43.

Tarlera, S., Muxí, L., Soubes, M. \& Stams, A. J. (1997). Caloramator proteoclasticus sp. nov., a new moderately thermophilic anaerobic proteolytic bacterium. Int J Syst Bacteriol 47, 651-656.

Tindall, B. J. (1990a). A comparative study of the lipid composition of Halobacterium saccharovorum from various sources. Syst Appl Microbiol 13, 128-130.

Tindall, B. J. (1990b). Lipid composition of Halobacterium lacusprofundi. FEMS Microbiol Lett 66, 199-202.
Tindall, B. J., Sikorski, J., Smibert, R. M. \& Krieg, N. R. (2007). Phenotypic characterization and the principles of comparative systematics. In Methods for General and Molecular Microbiology, 3rd edn, pp. 330-393. Edited by C. A. Reddy, T. J. Beveridge, J. A. Breznak, G. Marzluf, T. M. Schmidt \& L. R. Snyder. Washington, DC: American Society for Microbiology.

Wayne, L. G., Brenner, D. J., Colwell, R. R., Grimont, P. A. D., Kandler, O., Krichevsky, M. I., Moore, L. H., Moore, W. E. C., Murray, R. G. E. \& other authors (1987). International Committee on Systematic Bacteriology. Report of the ad hoc committee on reconciliation of approaches to bacterial systematics. Int J Syst Bacteriol 37, 463-464.

Weisburg, W. G., Barns, S. M., Pelletier, D. A. \& Lane, D. J. (1991). $16 \mathrm{~S}$ ribosomal DNA amplification for phylogenetic study. J Bacteriol 173, 697-703.

Wheals, A. E., Basso, L. C., Alves, D. M. G. \& Amorim, H. V. (1999). Fuel ethanol after 25 years. Trends Biotechnol 17, 482-487.

Wiegel, J., Ljungdahl, L. G. \& Demain, A. L. (1985). The importance of thermophilic bacteria in biotechnology. Crit Rev Biotechnol 3, 39-108.

Wyman, C. E. (1999). Biomass ethanol: technical progress, opportunities, and commercial challenges. Annu Rev Energy Environ 24, 189-226.

Yamamoto, K., Murakami, R. \& Takamura, Y. (1998). Isoprenoid quinone, cellular fatty acid composition and diaminopimelic acid isomers of newly classified thermophilic anaerobic Gram-positive bacteria. FEMS Microbiol Lett 161, 351-358.

Zaldivar, J., Nielsen, J. \& Olsson, L. (2001). Fuel ethanol production from lignocellulose: a challenge for metabolic engineering and process integration. Appl Microbiol Biotechnol 56, 17-34. 